\title{
PELATIHAN PENJUALAN ONLINE MENGGUNAKAN MARKETPLACE PADA UKM DI BANTUL
}

\author{
Keny Rahmawati \\ Universitas Pembangunan Nasional "Veteran" Yogyakarta \\ ${ }^{1}$ E-mail address keny.rahmawati@upnyk.ac.id
}

\begin{abstract}
At this time, information technology, especially the internet, has increased very rapidly. The increasing user of the interney in Indonesia has affected the development of e-commerce in Indonesia, especially the marketplace. One of the biggest marketplace player in Indonesia is Shopee. Based on data obtained form the Department of Cooperatives, MSMEs, and Industry of Bantul, currently there are 141 thousand MSMEs players who are covered by 351 cooperatives in Bantul. One of them is AMBOY (Agro Mirasa Boga Bantul Yogyakarta). The internet is used to help market business ventures through online sales by some cooperative members. However, some of members still sell in the traditional way. The constraint experienced by cooperative members is a lack of literacy regarding the use of the internet. Online sales training using marketplace is the right choice to overcome the obstacles faced by AMBOY Members. In this training, members of $A M B O Y$ will be taught how to sell their products in the marketplace in order to develop and expand their market.
\end{abstract}

Keywords: Marketplace, Selling, Shopee, Cooperatives

\begin{abstract}
Abstrak
Pada saat ini, teknologi informasi khususnya internet mengalami peningkatan yang sangat pesat. Meningkatnya penggunaan internet di Indonesia berpengaruh terhadap perkembangan e-commerce yang ada di Indonesia, khususnya marketplace. Salah satu marketplace yang terbesar adalah Shopee. Berdasarkan data yang didapat dari Dinas Koperasi, UMKM, dan Perindustrian Kabupaten Bantul, pada saat ini terdapat 141 ribu pelaku UMKM yang dinaungi oleh 351 koperasi yang berada di Kabupaten Bantul. Salah satunya adalah Koperasi AMBOY (Agro Mirasa Boga Bantul Yogyakarta). Internet dimanfaatkan untuk membantu memasarkan usaha bisnis melalui penjualan online oleh sebagian anggota Koperasi. Namun, sebagian lagi masih ada yang menjual dengan cara tradisional. Kendala yang dialami oleh anggota koperasi tersebut adalah kurangnya literasi mengenai pemanfaatan internet untuk membantu bisnis yang mereka jalani, dalam hal ini penjualan online. Pelatihan penjualan online merupakan pilihan yang tepat untuk mengatasi kendala yang dihadapi oleh anggota Koperasi AMBOY. Dalam pelatihan ini, anggota Koperasi AMBOY akan diajarkan bagaimana menjual produk mereka di marketplace untuk dapat mengembangkan dan memperluas pasar mereka.
\end{abstract}

Kata Kunci: Marketplace, Penjualan Online, Shopee, Koperasi 


\section{PENDAHULUAN}

Pada saat ini, teknologi informasi khususnya internet mengalami peningkatan yang sangat pesat. Internet membuka cakrawala yang luas dalam berbagai ruang lingkup kehidupan. Internet bukan merupakan hal asing bagi masyarakat saat ini. Masyarakat memanfaatkan internet untuk berbagai hal di kehidupan sehari-hari seperti berkomunikasi, media social, menonton televisi, membaca berita, mendengarkan music dilayanan streaming, hingga berbelanja. Perkembangan internet di Indonesia pun meningkat dengan pesat, hal ini ditandai dengan adanya kenaikan signifikan penetrasi internet setiap tahunnya. Berdasarkan data dari APJII (Asosiasi Pengguna Jasa Internet Indonesia) melalui survey pada tahun 2021 menunjukkan pengguna internet pada awal 2021 ini mencapai 202,6 juta jiwa. Jumlah ini meningkat 15,5\% atau 27 juta jiwa jika dibandingkan dengan 2020 lalu. (Riyanto, 2021)

Meningkatnya penggunaan internet di Indonesia berpengaruh terhadap perkembangan e-commerce yang ada di Indonesia, khususnya marketplace. E-commerce adalah proses pembelian dan penjualan jasa dan barang-barang secara elektronik dengan transaksi bisnis terkomputerisasi menggunakan internet, jaringan, dan teknologi digital lainnya. (C. Laudon dan P. Laudon, 2005). Pada saat ini belanja online menjadi pilihan terbaik bagi konsumen untuk dapat memenuhi kebutuhannya karena dapat memperoleh barang yang dibutuhkan tanpa harus banyak waktu dan tenaga, serta terdapat kemudahan dalam melakukan transaksi dan harga yang cukup kompetitif dengan kualitas barang yang bagus. Marketplace adalah sebuah wadah pemasaran produk secara elektronik yang mempertemukan banyak penjual dan pembeli untuk saling bertransaksi. (Apriadi, 2017). Melalui marketplace penjual tidak perlu bersusah payah ketika ingin melakukan kegiatan berjualan secara online. Penjual hanya perlu melakukan pendaftaran dan pembuatan akun di marketplace untuk memulai berjualan secara online. Setelah penjual berhasil membuat akun di marketplace, penjual hanya perlu meningkatkan pelayanan dan melakukan kegiatan promosi. Kemungkinan barang yang dijual di marketplace akan terjual lebih banyak karena marketplace merupakan tempat berkumpulnya penjual dan pembeli dari mana saja. Marketplace yang saat ini terdapat di Indonesia sudah sangat beragam seperti Tokopedia, Shopee, Bukalapak, Blili, JD.ID, dll. 
Berdasarkan data yang didapat dari Dinas Koperasi, UMKM, dan Perindustrian Kabupaten Bantul, pada saat ini terdapat 141 ribu pelaku UMKM yang dinaungi oleh 351 koperasi yang berada di Kabupaten Bantul. Salah satunya adalah Koperasi AMBOY (Agro Mirasa Boga Bantul Yogyakarta). Internet bukan hal asing bagi anggota Koperasi AMBOY. Penggunaan internet telah dimanfaatkan oleh anggota Koperasi AMBOY untuk berbagai aktivitas. Internet dimanfaatkan untuk membantu memasarkan usaha bisnis melalui penjualan online oleh sebagian anggota Koperasi. Namun, sebagian lagi masih ada yang menjual dengan cara tradisional. Kendala yang dialami oleh anggota koperasi tersebut adalah kurangnya literasi mengenai pemanfaatan internet untuk membantu bisnis yang mereka jalani, dalam hal ini penjualan online.

Pelatihan penjualan online merupakan pilihan yang tepat untuk mengatasi kendala yang dihadapi oleh anggota Koperasi AMBOY. Dalam pelatihan ini, anggota Koperasi AMBOY akan diajarkan bagaimana menjual produk mereka di marketplace untuk dapat mengembangkan dan memperluas pasar mereka.

\section{METODE DAN PELAKSANAAN}

\section{Metode}

Metode yang digunakan yaitu pelatihan dengan memberikan materi mengenai fungsi marketplace dan cara penggunaan dan pembuatan toko online di Shopee. Dalam kegiatan pelatihan ini dijelaskan mengenai bagaimana cara mengenai mengoptimalkan Shopee untuk meningkatkan penjualan mereka, yang dapat diakses bukan hanya melalui HP tapi juga dapat diakses melalui laptop/computer.

\section{Pelaksanaan Kegiatan}

Kegiatan pengabdian kepada masyarakat ini dilaksanakan pada tanggal 12 April 2021 pukul 10.00 - 12.00 yang berlokasi di Aula Koperas AMBOY (Agro Mirasa Boga Bantul Yogyakarta) Ponggok Sidomulyo Bambanglipuro Bantul D.I.Y. pada kegiatan kali ini dihadiri oleh anggota Koperasi AMBOY sebanyak 20 peserta. Latar belakang peserta pelatihan merupakan UMKM di bidang kuliner dan budi daya ikan.

\section{HASIL DAN PEMBAHASAN}

Solusi yang tepat untuk permasalahan yang dihadapi oleh Koperasi AMBOY adalah dengan memberikan pelatihan secara langsung kepada anggota Koperasi. Alat yang kami gunakan pada pelatihan kali ini adalah 
berupa meteri dalam bentuk pdf yang disampaikan langsung kepada peserta pelatihan.

Materi yang diberikan berisikan bagaimana cara penggunaan Shopee sebagai tempat berjualan produk yang mereka jual mulai dari membuat akun, mengupload produk, menarik dana, mempromosikan produknya di Shopee, dan lain sebagainya. Hasil yang diharapkan pada pelatihan kali ini adalah membuat anggota Koperasi AMBOY mampu menggunakan marketplace khususnya Shopee bukan hanya untuk berbelanja tetapi juga untuk berjualan. Adapun hasil lain yang diharapkan dalam pelatihan ini adalah sebagai berikut.

1. Meningkatkan pengetahuan anggota Koperasi AMBOY mengenai penggunaan dan manfaat marketplace.

2. Meningkatkan pemahaman dan kompetensi anggota Koperasi AMBOY dalam bidang teknologi khususnya manfaat marketplace untuk melakukan penjualan dan mempromosikan barang yang akan dijual.

Pada pelatihan kali ini, peserta diberikan materi mengenai jualan online melalui marketplace. Marketplace adalah sebuah wadah pemasaran produk secara elektronik yang mempertemukan banyak penjual dan pembeli untuk saling bertransaksi. Di Indonesia sendiri jumlah marketplace sudah sangat banyak seperti Tokopedia, Shopee, Bukalapak, Blili, JD.ID, dll. Terdapat beberapa hal yang perlu dilakukan dalam memilih marketplace untuk melakukan penjualan. (Kurniawan, 2018)

1. Mengetahui latar belakang dan reputasi marketplace

Pada saat ingin melakukan penjualan di marketplace, tips pertama yang harus penjual lakukan adalah mengetahui latar belakang dan reputasi marketplace. Latar belakang marketplace dapat diketahui dari sejarah berdiri, sistem kerja, dan testimoni pengguna marketplace tersebut. Informasi mengenai latar belakang marketplace bisa didapatkan melalui internet.

2. Cari situs marketplace yang ramai Marketplace yang memiliki reputasi yang baik, umumnya memiliki pasar yang ramai. Penjual dapat memastikan marketplace tersebut ramai dengan cara melihat data statistik jumlah pengunjung marketplace tersebut atau dengan cara melihat jumlah komentar dan ulasan yang terdapat pada marketplace tersebut. Manfaat 
dari berjualan di marketplace yang ramai adalah agar bisnis penjual dapat berpeluang untuk mendapatkan banyak pembeli yang akan menghasilkan banyak keuntungan bagi penjual.

3. Memiliki sistem yang memudahkan transaksi

Memiliki sistem transaksi yang mudah merupakan kunci bagi sebuah marketplace. Kemudahan sistem ini dapat dilihat dari katalog produk, sistem pesanan, sistem pembayaran, sistem tarik dana, dan lain sebagainya.

4. Memiliki layanan pelanggan yang mudah dihubungi

Marketplace yang baik adalah marketplace yang memiliki sistem yang bisa menjadi jembatan antara pembeli dan penjual dengan mudah. Alamat email, nomor kontak, media sosial, kotak pesan instan merupakan instrumen penting bagi sebuah marketplace untuk dapat meningkatkan layanan yang baik dengan para pelanggan.

5. Mempelajar fitur layanan

Setiap marketplace menyediakan berbagai maca fitur. Penjual harus bijak dalam menggunakan fitur tersebut. Pilihlah fitur yang dapat mendukung bisnis penjual.

6. Memahami prospek marketplace Mengetahui dan memahami prospek marketplace merupakan faktor penting. Kita harus mengetahui bagaimana perkembangan bisnis online kedepannya. Perkembangan tersebut dapat diketahui dengan cara meneliti, mengamati, dan mengevaluasi terkait perkembangan bisnis online.

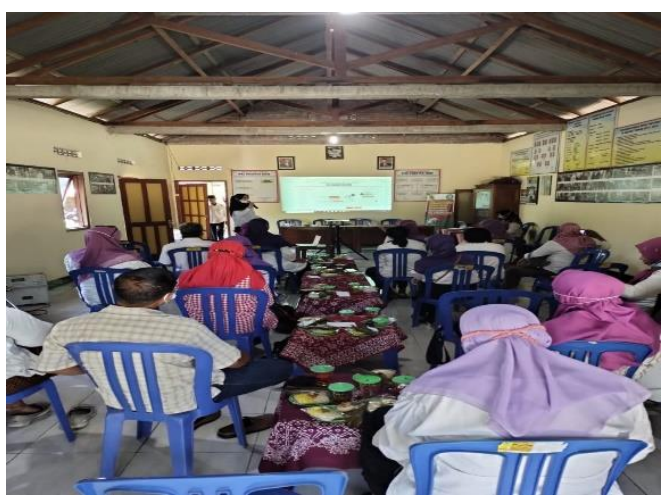

Gambar 1 Penyampaian Materi Penjualan Online

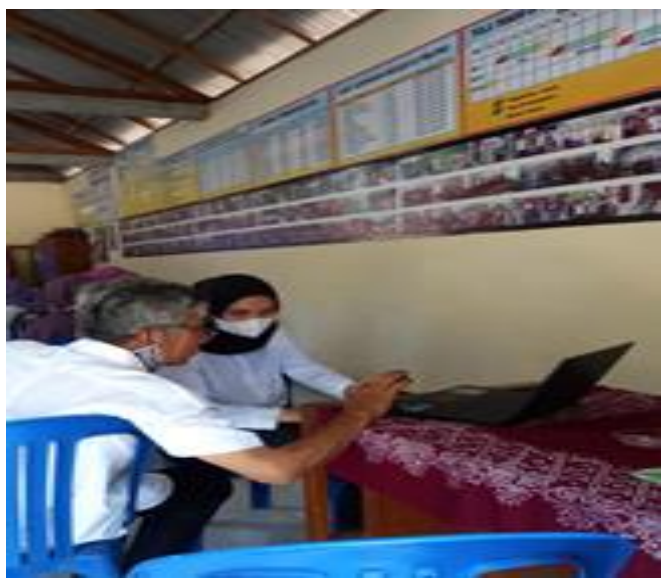

Gambar 2 Pelatihan Penjualan Online Materi disampaikan dengan ceramah terlebih dahulu dengan memberikan 
materi mengenai marketplace apa saja yang ada di Indonesia. Salah satu marketplace yang terbesar adalah Shopee. Selanjutnya, mulai dengan pelatihan mengenai tata cara penggunaan marketplace sebagai tempat berjualan online. Dalam hal ini marketplace yang digunakan adalah Shopee. Pada pelaksanaan kegiatan pelatihan penggunaan marketplace, peserta/anggota Koperasi AMBOY sangat antusias mengingat pentingnya penggunaan marketplace untuk perkembangan bisnisnya.

\section{PENUTUP}

\section{Simpulan}

Kegiatan pelatihan penggunaan marketplace sebagai tempat berjualan online di Koperasi AMBOY berjalan dengan lancar meskipun dengan berbagai kendala yang ada. Hal ini dibuktikan dengan antusias yang dirasakan oleh para peserta yang hadir dalam kegiatan pelatihan ini.

\section{Saran}

Dari kegiatan pelatihan ini terdapat beberapa saran yang diberikan, yaitu:

1. Kegiatan pelatihan dapat dikembangkan misalnya dengan menambah materi digital marketing.
2. Media praktik seperti laptop bisa ditambahkan tidak hanya menggunakan perangkat android.

\section{Ucapan Terima Kasih}

Kami sangat berterimakasih kepada warga masyarakat khususnya anggota Koperasi AMBOY atas partisipasinya dalam mengikuti acara pelatihan penggunaan marketplace untuk penjualan online. Semoga pelatihan yang telah dilaksanakan dapat bermanfaat dan diaplikasikan oleh seluruh anggota Koperasi AMBOY dalam menunjang bisnis yang sudah dijalankan selama ini. Selain itu kami juga berterimakasih kepada seluruh pihak yang terkait seperti LPPM UPN “Veteran” Yogyakarta.

\section{DAFTAR PUSTAKA}

Apriadi, Deni dan Saputra, A. Y., 2017. ECommerce Berbasis Marketplace Dalam Upaya Mempersingkat Distribusi Penjualan Hasil Pertanian. Jurnal RESTI Vol. 1 No. 2. Lubuklinggau: STMIK Bina Nusantara Jaya.

C. Laudon, Kenneth \& P. Laudon, Jane. 2005. Sistem Informasi Manajemen Mengelola Perusahaan Digital. Edisi 8. Yogyakarta: Andi Offset. 
Kurniawan, Suryadi. 2019. Marketplace

2021

dari

VS Toko Online: Jangan Asal Pilih

https://tekno.kompas.com/read/2

Ya!. Diakses 23 Mei 2021 dari 021/02/23/16100057/jumlah-

https://www.niagahoster.co.id/blo pengguna-internet-indonesia-2021$\mathrm{g} /$ marketplace-vs-toko-online/. tembus-202-juta .

Riyanto, Galuh Putri. 2021. Jumlah Pengguna Internet Indonesia 2021 Tembus 202 Juta. Diakses 23 Mei 